\title{
Postoperative pain management in patients undergoing posterior spinal fusion for adolescent idiopathic scoliosis: a narrative review
}

\author{
Hiroyuki Seki ${ }^{*}$ (ID, Satoshi Ideno ${ }^{1}$, Taiga Ishihara ${ }^{1}$, Kota Watanabe ${ }^{2}$, Morio Matsumoto ${ }^{2}$ and Hiroshi Morisaki ${ }^{1}$
}

\begin{abstract}
Posterior spinal fusion for adolescent idiopathic scoliosis is one of the most invasive surgical procedures performed in children and adolescents. Because of the extensive surgical incision and massive tissue trauma, posterior spinal fusion causes severe postoperative pain. Intravenous patient-controlled analgesia with opioids has been the mainstay of postoperative pain management in these patients. However, the use of systemic opioids is sometimes limited by opioid-related side effects, resulting in poor analgesia. To improve pain management while reducing opioid consumption and opioid-related complications, concurrent use of analgesics and analgesic modalities with different mechanisms of action seems to be rational. The efficacy of intrathecal opioids and nonsteroidal antiinflammatory drugs as components of multimodal analgesia in scoliosis surgery has been well established. However, there is either controversy or insufficient evidence regarding the use of other analgesic methods, such as continuous ketamine infusion, perioperative oral gabapentin, acetaminophen, continuous wound infiltration of local anesthetics, a single dose of systemic dexamethasone, and lidocaine infusion in this patient population. Moreover, appropriate combinations of analgesics have not been established. The aim of this literature review is to provide detailed information of each analgesic technique so that clinicians can make appropriate choices regarding pain management in patients with adolescent idiopathic scoliosis undergoing posterior spinal fusion.
\end{abstract}

Keywords: Analgesia, Pain management, Scoliosis, Spine surgery

\section{Background}

Adolescent idiopathic scoliosis (AIS) is a three-dimensional deformity of the spine defined as a lateral curvature of the spine in the coronal plane of more than $10^{\circ}$ with no known cause and a predilection for adolescent girls [1]. The degree of curvature is determined by the Cobb angle (formed by lines drawn along the superior endplate of the superior vertebra and the inferior endplate of the inferior vertebra). Surgical correction is indicated for AIS with severe deformity (Cobb angle $>45^{\circ}$ ), which can decrease the vital capacity of the lungs and interfere with everyday activity [2]. Posterior spinal fusion (PSF), which accounts for over $90 \%$ of surgical procedures performed for the correction of scoliosis,

\footnotetext{
* Correspondence: hseki@a3.keio.jp

${ }^{1}$ Department of Anesthesiology, Keio University School of Medicine, 35

Shinanomachi Shinjuku-ku, Tokyo 160-8582, Japan

Full list of author information is available at the end of the article
}

causes severe postoperative pain because of extensive dissection of the skin, subcutaneous tissues, bones, and ligaments. Innervation of these structures is via the posterior rami of the spinal nerves connected to the sympathetic and parasympathetic nerves, and various noxious stimuli, including mechanical irritation, compression, or postoperative inflammation, can cause pain [3]. In addition, the majority of patients with AIS who undergo PSF are young women, who are particularly susceptible to pain $[4,5]$. The causes of pain are complex, so the management of pain after scoliosis surgery is challenging. Inadequate pain management may not only diminish patients' satisfaction, but also result in delayed postoperative recovery, ambulation, discharge, and even persistent postoperative pain [6]. Historically, intravenous (IV) patient-controlled analgesia (PCA) with opioids has been the mainstay of pain management after scoliosis surgery. However, opioid-related

(c) The Author(s). 2018 Open Access This article is distributed under the terms of the Creative Commons Attribution 4.0 International License (http://creativecommons.org/licenses/by/4.0/), which permits unrestricted use, distribution, and 
adverse effects, such as nausea and vomiting, remain problematic for the majority of patients [7]. A recent trend has been to use more than one class of analgesic agent or technique concurrently to improve analgesia while reducing opioid consumption and opioid-related complications. Since the concept of multimodal analgesia was first introduced in the treatment of postoperative pain [8], its value has been well described, especially in joint arthroplasty [9]. Over the last few decades, various analgesics or analgesic modalities have been proposed as components of multimodal analgesia for scoliosis surgery, but there is either controversy or insufficient evidence regarding the use of these agents and modalities, so no optimal regimen has been established. The aim of this literature review is to provide detailed information on each analgesic technique so that clinicians can make choices regarding pain management in patients undergoing PSF for AIS.

\section{Methodology}

We searched the PubMed, Web of Science, and Cochrane Library to identify articles on postoperative analgesia in patients undergoing correction surgery for AIS using the keywords "scoliosis," "analgesia," "postoperative," and "children." One hundred and sixty-two potentially eligible records were retrieved. Articles were selected based on their relevance to the topic and limited to humans and publication in the English language up to November 2017. Case reports, case series, systematic reviews, meta-analyses, and scientific abstracts were excluded. Given that our focus was on postoperative pain management in patients undergoing PSF for AIS, articles that did not include PSF were excluded. After excluding 126 studies (63 duplicate publications, 10 review articles or meta-analyses, 10 case reports, 45 not relevant to the topic, 1 scientific abstract, 5 without clear details of the technique used, and 4 with inaccessible full text), 31 studies were included in the review. Additional references were identified from reference lists in the publications yielded by our initial search. This article was not intended to be a systematic review, so we did not apply the strict methodology recommended by PRISMA [10].

\section{Intravenous PCA}

PCA allows patients to self-administer analgesics, mainly opioids, intermittently as needed. IV PCA has been used as the "gold standard" treatment in adults with moderate to severe pain. There is also evidence showing that PCA is safe and effective in children [11]. Morphine-based IV PCA is the most commonly used form of postoperative analgesia in patients undergoing PSF for AIS [12, 13]. Morphine is generally administered as an initial loading dose of $0.05-0.1 \mathrm{mg} / \mathrm{kg}$ before the end of surgery, with PCA settings of a bolus dose of $0.01-0.03 \mathrm{mg} / \mathrm{kg}$, a lockout interval of 6-10 min, and a background infusion of 0.01-0.02 $\mathrm{mg} / \mathrm{kg} / \mathrm{h}$ [14-32] (Table 1). Some guidelines advise against the use of a background infusion in adults because of the potential for respiratory depression [33-35]. However, background infusion is widely used in children [36], who are considered to have a lower risk of respiratory depression [37, 38]. A study of the efficacy and safety of PCA in patients with AIS [14] found no difference between PCA alone and PCA with background infusion with regard to the postoperative use of morphine, side effects, or patient satisfaction and concluded that background infusion did not provide clinically significant advantages over intermittent bolus doses of morphine. The main adverse effects of IV PCA with morphine are nausea and vomiting $(20-80 \%)$ and pruritus (11-47\%), but clinically significant respiratory depression is rare. One retrospective study investigated the adverse effects of postoperative continuous morphine infusion without PCA (the infusion rate was titrated by increments of $0.005-0.01 \mathrm{mg} / \mathrm{kg} / \mathrm{h}$ to keep visual analog scale (VAS) pain scores at 5 or less, with a maximum infusion rate of $0.06 \mathrm{mg} / \mathrm{kg} / \mathrm{h}$ ) in combination with intrathecal morphine [39]. The incidences of postoperative nausea and vomiting (PONV) (13.3\%) and pruritus $(4.1 \%)$ were similar to those for PCA, and no cases of respiratory depression or admissions to the pediatric intensive care unit were reported. In addition to morphine, oxycodone $(0.025 \mathrm{mg} / \mathrm{kg}$ every $10 \mathrm{~min}$ on demand with a 4-h maximum of $0.3 \mathrm{mg} / \mathrm{kg}$ ) was also used for PCA [32].

In summary, IV PCA with morphine is the best established and most widely used analgesia technique for scoliosis correction surgery. However, considering the high incidence of minor complications, such as postoperative nausea and vomiting (PONV) and pruritus, other techniques should be considered for the combination with IV PCA to minimize the use of morphine.

\section{Epidural analgesia}

Epidural analgesia is also widely used as an adjunct to IV PCA for postoperative analgesia in patients undergoing PSF for scoliosis [16, 20, 25, 31, 40-43]. However, no standard methods have been established. Although an epidural catheter is always placed by the surgeon prior to the closure of the surgical wound, the numbers and positions of the catheters inserted, the types and amounts of agents used, and the mode of administration vary widely in the literature (Table 2). Recent meta-analyses show that epidural analgesia is superior in analgesic effect when compared with IV PCA, making it possible to reduce the amount of analgesics used postoperatively [32, 33]. However, the success rate varies depending on the report. In a retrospective study that compared postoperative epidural analgesia $(n=413)$ and IV PCA $(n=200)$, the averages of all pain scores and scores at 2, 4, 6, 8, 12, 24, 36, and $48 \mathrm{~h}$ were significantly better in the epidural analgesia group. 
Table 1 Regimens for intravenous patient-controlled analgesia reported in the literature

\begin{tabular}{|c|c|c|c|c|}
\hline $\begin{array}{l}\text { First author } \\
\text { Journal } \\
\text { Year } \\
\text { Type of study } \\
\text { Total sample size }\end{array}$ & Loading & PCA bolus & Lockout interval & Basal infusion \\
\hline $\begin{array}{l}\text { Weldon [14] } \\
\text { Clin J Pain } \\
1993 \\
\text { RCT } \\
54\end{array}$ & None & $\begin{array}{l}\text { Morphine sulfate } 0.03 \mathrm{mg} / \mathrm{kg} \\
\text { (PCA bolus alone) or } 0.02 \mathrm{mg} / \mathrm{kg} \\
\text { (PCA bolus + basal infusion) }\end{array}$ & & $\begin{array}{l}\text { None (PCA bolus alone) } \\
\text { or morphine sulfate } 0.02 \mathrm{mg} / \mathrm{kg} / \mathrm{h} \\
\text { (PCA bolus }+ \text { basal infusion) }\end{array}$ \\
\hline $\begin{array}{l}\text { Beaulieu [15] } \\
\text { Int Orthop } \\
1996 \\
\text { Observational } \\
100\end{array}$ & $\begin{array}{l}\text { Morphine } \\
114.5 \mu \mathrm{g} / \mathrm{kg}\end{array}$ & Morphine 24.8 mg/kg & $9.9 \min$ & None \\
\hline $\begin{array}{l}\text { Cassady [16] } \\
\text { Reg Anesth Pain Med } \\
2000 \\
\text { RCT } \\
33\end{array}$ & None & Morphine sulfate $0.02 \mathrm{mg} / \mathrm{kg}$ & $\begin{array}{l}8-\mathrm{min} \text { and } 4 \text {-h limit of } \\
0.2 \mathrm{mg} / \mathrm{kg}\end{array}$ & None \\
\hline $\begin{array}{l}\text { Munro [17] } \\
\text { Can J Anaesth } \\
2002 \\
\text { RCT } \\
35\end{array}$ & $\begin{array}{l}\text { Morphine } \\
0.05-0.1 \mathrm{mg} / \mathrm{kg}\end{array}$ & Morphine $0.02 \mathrm{mg} / \mathrm{kg}$ & No description & Morphine $0.01 \mathrm{mg} / \mathrm{kg} / \mathrm{h}$ \\
\hline $\begin{array}{l}\text { Sucato [18] } \\
\text { Spine (Phila Pa 1976) } \\
2005 \\
\text { Retrospective } \\
613\end{array}$ & None & $\begin{array}{l}\text { Morphine } 0.02-0.03 \mathrm{mg} / \mathrm{kg} \text { or meperidine } \\
0.2-0.3 \mathrm{mg} / \mathrm{kg}\end{array}$ & $\begin{array}{l}7-12 \text { min with a limit of } 4-5 \\
\text { injections } / \mathrm{h}\end{array}$ & $\begin{array}{l} \pm \text { Morphine } 0.015 \mathrm{mg} / \mathrm{kg} / \mathrm{h} \\
\text { or meperidine } 0.15 \mathrm{mg} / \mathrm{kg} / \mathrm{h}\end{array}$ \\
\hline $\begin{array}{l}\text { Crawford [19] } \\
\text { Anesth Analg } \\
2006 \\
\text { RCT } \\
30\end{array}$ & $\begin{array}{l}\text { Morphine } \\
100 \mu \mathrm{g} / \mathrm{kg}\end{array}$ & Morphine 20 g/kg & $6 \mathrm{~min}$ & Morphine $10 \mu \mathrm{g} / \mathrm{kg} / \mathrm{h}$ \\
\hline $\begin{array}{l}\text { Gauger [20] } \\
\text { J Pediatr Orthop } \\
2009 \\
\text { RCT } \\
67\end{array}$ & None & Hydromorphone $2 \mu \mathrm{g} / \mathrm{kg}$ & $\begin{array}{l}10-\mathrm{min} \text { and } 4-\mathrm{h} \text { limit } \\
\text { of } 20 \mu \mathrm{g} / \mathrm{kg}\end{array}$ & Hydromorphone $2 \mu \mathrm{g} / \mathrm{kg} / \mathrm{h}$ \\
\hline $\begin{array}{l}\text { Milbrandt [21] } \\
\text { Spine (Phila Pa 1976) } \\
2009 \\
\text { Retrospective } \\
136\end{array}$ & None & Morphine $0.01-0.02 \mathrm{mg} / \mathrm{kg}$ & $\begin{array}{l}6-10 \text { min with a limit } \\
\text { of } 4-5 \text { injections/h }\end{array}$ & \pm Morphine $0.02 \mathrm{mg} / \mathrm{kg} / \mathrm{h}$ \\
\hline $\begin{array}{l}\text { Sadhasivam [22] } \\
\text { J Clin Anesth } \\
2009 \\
\text { Retrospective } \\
131\end{array}$ & None & Morphine $20 \mu \mathrm{g} / \mathrm{kg}$ & $7 \mathrm{~min}$ & Morphine $10 \mu \mathrm{g} / \mathrm{kg} / \mathrm{h}$ \\
\hline $\begin{array}{l}\text { Wade [23] } \\
\text { Spine Deform } \\
2015 \\
\text { Retrospective } \\
196\end{array}$ & None & 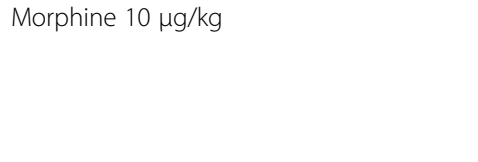 & $10 \mathrm{~min}$ & Morphine $10 \mu \mathrm{g} / \mathrm{kg} / \mathrm{h}$ \\
\hline $\begin{array}{l}\text { Mayell [24] } \\
\text { Pediatr Anaesth } \\
2014 \\
\text { RCT } \\
35\end{array}$ & None & 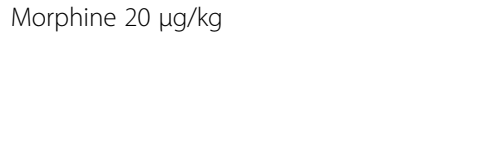 & $6 \min$ & $\begin{array}{l}\text { Morphine } 10 \mu \mathrm{g} / \mathrm{kg} / \mathrm{h} \text { for the first } \\
\text { day }\end{array}$ \\
\hline $\begin{array}{l}\text { Klatt [25] } \\
\text { Spine (Phila Pa 1976) } \\
2013 \\
\text { RCT } \\
66\end{array}$ & Up to $0.2 \mathrm{mg} / \mathrm{kg}$ & Morphine $20 \mu \mathrm{g} / \mathrm{kg}$ & $\begin{array}{l}10 \text { min with a limit of } \\
4 \text { demand doses/h }\end{array}$ & Morphine 20 mg/kg/h \\
\hline
\end{tabular}


Table 1 Regimens for intravenous patient-controlled analgesia reported in the literature (Continued)

\begin{tabular}{|c|c|c|c|c|}
\hline $\begin{array}{l}\text { First author } \\
\text { Journal } \\
\text { Year } \\
\text { Type of study } \\
\text { Total sample size }\end{array}$ & Loading & PCA bolus & Lockout interval & Basal infusion \\
\hline $\begin{array}{l}\text { Choudhry [26] } \\
\text { J Pediatr Orthop } \\
2017 \\
\text { Retrospective } \\
127\end{array}$ & None & Morphine $1.0 \mathrm{mg}$ & $\begin{array}{l}10 \text { min with a } 4-\mathrm{h} \\
\text { maximum } \\
\text { dose of } 0.3 \mathrm{mg} / \mathrm{kg}\end{array}$ & Morphine $20 \mu \mathrm{g} / \mathrm{kg} / \mathrm{h}$ \\
\hline $\begin{array}{l}\text { Perello [27] } \\
\text { Spine (Phila Pa 1976) } \\
2017 \\
\text { RCT } \\
44\end{array}$ & None & Morphine hydrochloride $20 \mu \mathrm{g} / \mathrm{kg}$ & & $\begin{array}{l}\text { Morphine hydrochloride } 5 \text { mg/kg/ } \\
\text { h }\end{array}$ \\
\hline $\begin{array}{l}\text { Pestieau [28] } \\
\text { Pediatr Anesth } \\
2014 \\
\text { RCT } \\
50\end{array}$ & None & Morphine 20 mg/kg & $8 \min$ & Morphine $20 \mu \mathrm{g} / \mathrm{kg} / \mathrm{h}$ \\
\hline $\begin{array}{l}\text { Rusy [29] } \\
\text { Anesth Analg } \\
2010 \\
\text { RCT } \\
59\end{array}$ & None & Morphine $0.02 \mathrm{mg} / \mathrm{kg}$ & $\begin{array}{l}6 \mathrm{~min} \text { and an hourly } \\
\text { maximum of } 0.12 \mathrm{mg} / \mathrm{kg}\end{array}$ & Morphine $0.02 \mathrm{mg} / \mathrm{kg} / \mathrm{h}$ \\
\hline $\begin{array}{l}\text { Engelhardt [30] } \\
\text { Anesth Analg } \\
2008 \\
\text { RCT } \\
34\end{array}$ & None & Morphine $20 \mu \mathrm{g} / \mathrm{kg}$ & $6 \mathrm{~min}$ & Morphine $10 \mu \mathrm{g} / \mathrm{kg} / \mathrm{h}$ \\
\hline $\begin{array}{l}\text { O'Hara [31] } \\
\text { Pediatr Anesth } \\
2004 \\
\text { RCT } \\
31\end{array}$ & None & $\begin{array}{l}\text { Morphine } 1 \mathrm{mg}(\mathrm{BW}>50 \mathrm{~kg}) \text { or } 20 \mathrm{\mu g} / \mathrm{kg} \\
(\mathrm{BW}<50 \mathrm{~kg})\end{array}$ & $\begin{array}{l}6 \text { min with } 10 \text { possible } \\
\text { doses/h }\end{array}$ & None \\
\hline $\begin{array}{l}\text { Hiller [32] } \\
\text { Spine (Phila Pa 1976) } \\
2012 \\
\text { RCT } \\
36\end{array}$ & None & Oxycodone 0.025 mg/kg & $\begin{array}{l}\text { 10-min and 4-h maximum } \\
\text { of } 0.3 \mathrm{mg} / \mathrm{kg}\end{array}$ & None \\
\hline
\end{tabular}

$B W$ body weight, $P C A$ patient-controlled analgesia, $R C T$ randomized controlled trial

However, the need for temporary cessation and permanent discontinuation of pain management was greater in the epidural analgesia group than in the IV PCA group ( $12.3 \%$ vs $7.0 \%$ and $13.1 \%$ vs $0.0 \%$, respectively) [18]. The most common reasons for temporary cessation of epidural analgesia in the 413 patients were respiratory depression ( $n=30,7.3 \%)$, neurologic changes $(n=13,3.1 \%)$, and oversedation $(n=3,0.7 \%)$. The neurologic changes were mild asymmetric differences in the sensation of light touch on the lower extremities that resolved after temporary cessation of the epidural infusion. The most common reasons for permanent discontinuation of epidural analgesia were uncontrollable pain $(n=33,8.0 \%)$ and neurologic changes $(n=8,2.1 \%)$. There were no permanent neurologic injuries. In a small randomized controlled trial that compared epidural analgesia $(n=19)$ and IV PCA $(n=19)$, seven patients $(37 \%)$ in the epidural analgesia group experienced poor analgesia and required a change to IV PCA within $24 \mathrm{~h}$, although the average and lowest pain scores on postoperative days 2 and 3 were significantly lower in the epidural group [20]. In contrast, an observational study that assessed 98 consecutive patients undergoing PSF who received epidural analgesia reported insufficient analgesia in only 3 patients [41]. In that study, there were no adverse events in 87 patients. The most common complications were hypotension $(n=3)$, insufficient analgesia $(n=3)$, and displacement of the epidural catheter $(n=2)$. The epidural catheter was removed on postoperative day 2 in one patient because of the development of a leak at the skin level. There was a further patient in whom a leak into the spinal space was suspected because of prolonged muscle weakness. It is likely that the efficacy and safety of epidural analgesia depend on the experience of health care providers. The frequency of the most common minor 
Table 2 Regimens for continuous epidural analgesia reported in the literature

\begin{tabular}{lll}
\hline First author Catheter position & Loading & Continuous infusion \\
Journal & & PCEA \\
Year & & \\
Type of study & & \\
Total sample & &
\end{tabular}

\begin{tabular}{|c|c|}
\hline $\begin{array}{l}\text { Cassady [16] } \\
\text { Reg Anesth Pain } \\
\text { Med } \\
2000 \\
\text { RCT } \\
33\end{array}$ & $\begin{array}{l}\text { At the midpoint of the incis } \\
\text { and advanced } 3-5 \mathrm{~cm} \\
\text { cephalad }\end{array}$ \\
\hline $\begin{array}{l}\text { Tobias [42] } \\
\text { Paediatr } \\
\text { Anaesth } \\
2001 \\
\text { Observational } \\
14\end{array}$ & $\begin{array}{l}\text { Upper catheter: at the T6-8 } \\
\text { level with the tip directed } \\
\text { cephalad to T1-4. } \\
\text { Lower catheter: at the T12 } \\
\text { level with the tip directed } \\
\text { caudad to the L1-4 level. }\end{array}$ \\
\hline
\end{tabular}

Blumenthal
[40]
Anesthesiology
2005
RCT
30

Upper catheter: at the cranial end of the wound and the tip directed $4-5 \mathrm{~cm}$ cephalad to T1-4. The lower catheter was inserted at the caudal end of the wound, and the tip was directed 4-5 cm to a position at L1-4.

O'Hara [31]
Paediatr
Anaesth
2004
RCT
31
Saudan [41]
Paediatr
Anaesth
2008
Observational
98

At the midpoint of the incision and advanced 3-5 cm cephalad

Single: the catheter tip was in the center of the surgical site.

Double: the cranial catheter was set between thoracic levels T4 and T6 and the lower catheter between $\mathrm{T} 10$ and $\mathrm{L} 1$

$\begin{array}{ll}\text { Gauger [20] } & \text { At the midpoint of the } \\ \text { J Pediatr } & \text { incision and advanced } \\ \text { Orthop } & 3-5 \mathrm{~cm} \text { cephalad } \\ 2009 & \end{array}$

38

Klatt [25] Single: at the midpoint of the

Spine (Phila Pa incision and advanced $3-5 \mathrm{~cm}$ 1976) cephalad

2013 Double: the upper catheter was

RCT placed at the junction of the

66 proximal and middle thirds of the instrumented spine and advanced $5 \mathrm{~cm}$ cephalad.

The lower catheter was placed at the junction of the middle and distal thirds of the instrumented spine and advanced $5 \mathrm{~cm}$ cephalad.

Bupivacaine $0.25 \%$ with epinephrine 1:200,000, $10 \mathrm{ml}$, 15 min before skin closure

Bupivacaine 0.125\%

(0.35 mg/ $\mathrm{kg} / \mathrm{h}$ ) and fentanyl

$2.5 \mu \mathrm{g} / \mathrm{ml}(0.7 \mu \mathrm{g} / \mathrm{kg} / \mathrm{h})$,

$0.28 \mathrm{ml} / \mathrm{kg} / \mathrm{h}$, within $30 \mathrm{~min}$

of arrival in the PACU

Fentanyl $1 \mu \mathrm{g} / \mathrm{kg}$ and hydromorphone $5 \mu \mathrm{g} / \mathrm{kg}$ were diluted in $0.3 \mathrm{ml} / \mathrm{kg}$ of saline. Following placement, the upper and lower catheters were dosed with $0.1 \mathrm{ml} / \mathrm{kg}$ and $0.2 \mathrm{ml} / \mathrm{kg}$ of the solution, respectively.

After tracheal extubation and neurologic examination, the catheters were dosed with $0.1 \mathrm{ml} / \mathrm{kg}$ of ropivacaine $0.2 \%$ (upper catheter) and $0.2 \mathrm{ml} / \mathrm{kg}$ of ropivacaine $0.2 \%$ (lower catheter)

Ropivacaine 0.3\% 4-8-ml Ropivacaine 0.3\% 4-10 ml/h boluses through each catheter. in each catheter after the bolus doses of ropivacaine

Bupivacaine $0.1 \%$ or $0.065 \%$ + fentanyl $5 \mu \mathrm{g} / \mathrm{ml}, 3 \mathrm{ml}$ before conclusion of surgery

Ropivacaine $0.1 \%$ and hydromorphone $10 \mu \mathrm{g} / \mathrm{ml}$ at $0.1 \mathrm{ml} / \mathrm{kg} / \mathrm{h}$ into the upper catheter and $0.2 \mathrm{ml} / \mathrm{kg} / \mathrm{h}$ into the lower catheter, started after the bolus doses of ropivacaine

None

None

(1) \\ None
}


Table 2 Regimens for continuous epidural analgesia reported in the literature (Continued)

\begin{tabular}{|c|c|c|c|c|}
\hline $\begin{array}{l}\text { First author } \\
\text { Journal } \\
\text { Year } \\
\text { Type of study } \\
\text { Total sample } \\
\text { size }\end{array}$ & Catheter position & Loading & Continuous infusion & PCEA \\
\hline $\begin{array}{l}\text { Erdogan [43] } \\
\text { Spine (Phila Pa } \\
\text { 1976) } \\
2017 \\
\text { RCT } \\
44\end{array}$ & $\begin{array}{l}\text { At the midpoint of the incision } \\
\text { and advanced } 5-6 \mathrm{~cm} \text { cephalad } \\
\text { to T4 to T5 }\end{array}$ & $\begin{array}{l}\text { Morphine } 50 \mu \mathrm{g} / \mathrm{kg} \text { in a } \\
\text { PCIEA group and } 20 \mu \mathrm{g} / \mathrm{kg} \\
\text { in a PCCEA group }\end{array}$ & $\begin{array}{l}\text { No continuous infusion in } \\
\text { the PCIEA group and } \\
\text { morphine } 10 \mu \mathrm{g} / \mathrm{kg} / \mathrm{h} \\
\text { in the PCCEA group }\end{array}$ & $\begin{array}{l}50 \mathrm{\mu g} / \mathrm{kg} / \mathrm{h} \text { with a } 1-\mathrm{h} \\
\text { lockout in PCIEA group and } \\
5 \mathrm{\mu g} / \mathrm{kg} \text { bolus dose with a } \\
30-\mathrm{min} \text { lockout interval and } \\
4 \text {-h limit of } 4 \mathrm{mg}\end{array}$ \\
\hline
\end{tabular}

complications, such as PONV (in up to $85.7 \%$ of cases) and pruritus (in up to $42.9 \%$ ), also varies depending on the report. Some studies have shown that epidural analgesia has a lower incidence of these adverse effects than IV PCA, while others have found no difference between the two techniques. There are some epidural analgesia-specific complications. In a randomized controlled study, 4 of 15 patients showed motor blockade of more than one (with a modified Bromage scale score of 2 in one patient and 3 in three patients) after receiving an initial bolus of epidural ropivacaine [40]. The blockade spontaneously resolves within $180 \mathrm{~min}$ but might interfere with the neurologic assessment. Thus, the neurologic function should be assessed before administering a loading dose of epidural analgesia. In another randomized controlled trial that compared epidural analgesia and IV PCA, urinary retention was observed in 3 of 22 patients in the epidural group. Although the incidence of urinary retention was not different between the two analgesic techniques, postoperative epidural analgesia has been reported to be associated with a higher incidence of urinary retention than IV PCA [44]. No epidural analgesia-related infections have been reported, but because of the small sample sizes in most of the studies, the risk of these infections is not completely excluded.

In summary, epidural analgesia is effective as a postoperative analgesia strategy and may provide better analgesia than IV PCA in patients undergoing PSF for AIS. However, it should be used with caution because there might be some drawbacks, such as the problem of inadequate assessment of motor function and the need to retain the urinary catheter.

\section{Intrathecal opioids}

Intrathecal administration of opioids is another analgesic strategy [45-51]. In most reports, morphine 5-20 $\mu \mathrm{g} / \mathrm{kg}$ alone or in combination with sufentanil $1 \mu \mathrm{g} / \mathrm{kg}$ and diluted in $2-4 \mathrm{ml}$ of saline was administered intrathecally by an anesthesiologist after the induction of anesthesia and before the surgical incision. The results of these studies show that intrathecal opioids (ITO) can reduce intraoperative opioid use as well as early postoperative opioid consumption and pain scores, but the analgesic effect does not last for more than $24 \mathrm{~h}[21,45-48,50,51]$ (Table 3). Therefore, this method is used in combination with IV PCA. It has been shown that ITO reduce intraoperative blood loss by 65\% [45-47], although the mechanism of the blood-sparing effect of ITO is unclear. Some studies found that mean arterial pressure was lower in patients who received ITO than in those who did not, but other studies found no difference in the mean arterial pressure between these two groups. There was no difference in the frequency of nausea and vomiting (25.2-90\%) or pruritus (4.3-80\%) between patients who received ITO and those who received IV PCA alone. The incidence of clinically significant respiratory depression with ITO is reported to be similar to that with IV PCA, but a higher ITO dose (morphine $\geq 20 \mu \mathrm{g} / \mathrm{kg}$ ) may increase the risk of clinically significant respiratory depression [48]. There are no reports of increased rates of spinal anesthesia-related complications, such as nerve injury, hematoma, or infection with ITO, but again, the possibility of these adverse events is not completely excluded because of the small sample sizes in most studies.

In summary, ITO is effective for the reduction of opioid consumption and pain intensity in the early postoperative period after scoliosis correction surgery. Further, ITO is associated with less intraoperative blood loss. However, a higher ITO dose (morphine $\geq 20 \mu \mathrm{g} / \mathrm{kg}$ ) should be avoided in view of the potential risk of respiratory depression.

\section{Ketamine}

Ketamine is an anesthetic agent that works by binding to the $N$-methyl-D-aspartate receptor and has an analgesic effect at subanesthetic doses. Recent meta-analyses have shown that supplemental perioperative ketamine decreases the intensity of postoperative pain and cumulative morphine consumption without increasing adverse events in patients undergoing various types of surgery 
Table 3 Regimens for intrathecal opioids reported in the literature

\begin{tabular}{|c|c|c|c|c|}
\hline $\begin{array}{l}\text { First author } \\
\text { Journal } \\
\text { Year } \\
\text { Type of study } \\
\text { Total sample size }\end{array}$ & Timing of administration & Solution & Site & Needle \\
\hline $\begin{array}{l}\text { Goodarzi [45] } \\
\text { Paediatr Anaesth } \\
1998 \\
\text { RCT } \\
80\end{array}$ & After tracheal intubation & $\begin{array}{l}2 \mu \mathrm{g} / \mathrm{kg} \text { morphine mixed with } 50 \mu \mathrm{g} \text { of sufentanil } \\
\text { and } 2 \mathrm{ml} \text { of preservative-free saline }\end{array}$ & $\begin{array}{l}\text { At the level } \\
\text { of } L 3-4\end{array}$ & $\begin{array}{l}\text { A 24-gauge } \\
\text { spinal needle }\end{array}$ \\
\hline $\begin{array}{l}\text { Gall [46] } \\
\text { Anesthesiology } \\
2001 \\
\text { RCT } \\
30\end{array}$ & After tracheal intubation & $\begin{array}{l}\text { 4-ml solution containing } 2 \mu \mathrm{g} / \mathrm{kg} \text { preservative-free } \\
\text { morphine, } 5 \mu \mathrm{g} / \mathrm{kg} \text { preservative-free morphine, } \\
\text { or normal saline }\end{array}$ & No description & $\begin{array}{l}\text { A 25-gauge } \\
\text { pencil-point } \\
\text { spinal needle }\end{array}$ \\
\hline $\begin{array}{l}\text { Eschertzhuberl [47] } \\
\text { Br J Anaesth } \\
2008 \\
\text { RCT } \\
42\end{array}$ & After tracheal intubation & $\begin{array}{l}\text { A mixture of } 1 \mu \mathrm{g} / \mathrm{kg} \text { sufentanil and } 5 \text { or } 15 \mu \mathrm{g} / \mathrm{kg} \\
\text { morphine diluted with normal saline to a total } \\
\text { volume of } 3 \mathrm{ml}\end{array}$ & $\begin{array}{l}\text { At the level of } \\
L 3-4 \text { or } L 4-5\end{array}$ & $\begin{array}{l}\text { A } 25 \text {-gauge } \\
\text { pencil-point } \\
\text { spinal needle }\end{array}$ \\
\hline $\begin{array}{l}\text { Tripi [48] } \\
\text { Spine (Phila Pa 1976) } \\
2008 \\
\text { Retrospective } \\
407\end{array}$ & $\begin{array}{l}\text { After induction of general } \\
\text { anesthesia and before } \\
\text { surgical incision }\end{array}$ & $\begin{array}{l}\text { No dose, moderate dose; morphine 9-19 } \mathrm{\mu g} / \mathrm{kg} \\
\text { or high dose } \geq 20 \mu \mathrm{g} / \mathrm{kg}\end{array}$ & No description & No description \\
\hline $\begin{array}{l}\text { Son-Hing [49] } \\
\text { J Pediatr Orthop } \\
2011 \\
\text { Retrospective } \\
287\end{array}$ & $\begin{array}{l}\text { After induction of general } \\
\text { anesthesia and before } \\
\text { surgical incision }\end{array}$ & Morphine 9-19 $\mu \mathrm{g} / \mathrm{kg}$ & No description & No description \\
\hline $\begin{array}{l}\text { Hong [50] } \\
\text { Paediatr Anaesth } \\
2017 \\
\text { Retrospective } \\
40\end{array}$ & $\begin{array}{l}\text { Immediately after induction of } \\
\text { anesthesia and prior to incision }\end{array}$ & Morphine $12 \mu \mathrm{g} / \mathrm{kg}$ & No description & No description \\
\hline $\begin{array}{l}\text { Cohen [51] } \\
\text { Anesth Analg } \\
2017 \\
\text { RCT } \\
71\end{array}$ & $\begin{array}{l}\text { After placement of } \\
\text { an endotracheal tube }\end{array}$ & $\begin{array}{l}\text { Preservative-free morphine at } \\
\text { a concentration of } 7.5 \mu \mathrm{g} / \mathrm{kg}\end{array}$ & $\begin{array}{l}\text { Between levels L2 } \\
\text { and L5 }\end{array}$ & $\begin{array}{l}\text { A 24-gauge } \\
\text { spinal needle }\end{array}$ \\
\hline
\end{tabular}

$[52,53]$. The recent guidelines recommend consideration of IV ketamine as a component of multimodal analgesia [34]. However, the postoperative analgesic effect of adjuvant ketamine in patients undergoing scoliosis correction surgery for AIS is controversial. Table 4 shows the regimens for continuous ketamine infusion reported in the literature. In one randomized controlled trial, 34 patients were assigned to receive either intraoperative low-dose ketamine (a bolus dose of $0.5 \mathrm{mg} / \mathrm{kg}$ followed by a continuous infusion of $0.24 \mathrm{mg} / \mathrm{kg}$ until extubation, $n=16)$ or the same volume of saline $(n=18)$ [30]. Intraoperative low-dose ketamine failed to decrease the cumulative morphine consumption, the pain scores, or the frequency of PONV and pruritus at $72 \mathrm{~h}$ after PSF when compared with the saline-treated group. In another randomized controlled trial, patients who received ketamine as a bolus dose of $0.5 \mathrm{mg} / \mathrm{kg}$ prior to the surgical incision, an intraoperative infusion at $0.25 \mathrm{mg} / \mathrm{kg} / \mathrm{h}$, and a postoperative infusion at $0.1 \mathrm{mg} / \mathrm{kg} / \mathrm{h}$ for $72 \mathrm{~h}$ $(n=29)$ had morphine consumption and sedation and pain scores that were similar to those in a saline-treated group $(n=21)$ for $96 \mathrm{~h}$ postoperatively [28]. One randomized controlled trial failed to show beneficial effects of ketamine (administered as a $0.5 \mathrm{mg} / \mathrm{kg}$ bolus at induction of anesthesia followed by a continuous infusion of $2 \mu \mathrm{g} / \mathrm{kg} / \mathrm{min}$ until $72 \mathrm{~h}$ postoperatively) on either short-term outcomes, i.e., postoperative morphine use, pain scores, and side effects, or the long-term outcome, i.e., incidence of pain after discharge from hospital [27]. In contrast, it has been reported that perioperative low-dose ketamine (a bolus dose of $0.5 \mathrm{mg} / \mathrm{kg}$, followed by $48 \mathrm{~h}$ of continuous infusion of $0.12 \mathrm{mg} / \mathrm{kg} / \mathrm{h}, n=17$ ) decreased the cumulative morphine consumption by $20 \%$ when compared with a control group $(n=19)$ at 24 and $48 \mathrm{~h}$ after surgery. In that study, pain scores, sedation scale scores, and the incidence of PONV did not 
Table 4 Regimens for continuous ketamine infusion reported in the literature

\begin{tabular}{|c|c|c|c|}
\hline $\begin{array}{l}\text { First author } \\
\text { Journal } \\
\text { Year } \\
\text { Type of study } \\
\text { Total sample size }\end{array}$ & Loading dose & Intraoperative infusion & Postoperative infusion \\
\hline $\begin{array}{l}\text { Engelhardt [30] } \\
\text { Anaesth Analg } \\
2008 \\
\text { RCT } \\
34\end{array}$ & $\begin{array}{l}0.5 \mathrm{mg} / \mathrm{kg} \text { (no description regarding } \\
\text { the time of bolus administration) }\end{array}$ & $\begin{array}{l}4 \mu \mathrm{gg} / \mathrm{kg} / \mathrm{min} \text { started after bolus dose and } \\
\text { discontinued after surgery at the time of } \\
\text { tracheal extubation }\end{array}$ & None \\
\hline $\begin{array}{l}\text { Pestieau [28] } \\
\text { Paediatr Anaesth } \\
2014 \\
\text { RCT } \\
50\end{array}$ & $\begin{array}{l}0.5 \mathrm{mg} / \mathrm{kg} \text { immediately after the } \\
\text { patient was positioned prone }\end{array}$ & $0.25 \mathrm{mg} / \mathrm{kg} / \mathrm{h}$ & $0.1 \mathrm{mg} / \mathrm{kg} / \mathrm{h}$ infused for $72 \mathrm{~h}$ \\
\hline $\begin{array}{l}\text { Minoshima [54] } \\
\text { Acta Anaesthesiol Scand } \\
2015 \\
\text { RCT } \\
36\end{array}$ & $0.5 \mathrm{mg} / \mathrm{kg}$ after tracheal intubation & $2 \mu \mathrm{g} / \mathrm{kg} / \mathrm{min}$ started after loading dose & $2 \mu \mathrm{g} / \mathrm{kg} / \mathrm{min}$ for $48 \mathrm{~h}$ \\
\hline $\begin{array}{l}\text { Perello [27] } \\
\text { Spine (Phila Pa 1976) } \\
2017 \\
\text { RCT } \\
44\end{array}$ & $0.5 \mathrm{mg} / \mathrm{kg}$ at induction of anesthesia & $2 \mu \mathrm{g} / \mathrm{kg} / \mathrm{min}$ & $2 \mu \mathrm{g} / \mathrm{kg} / \mathrm{min}$ for $72 \mathrm{~h}$ \\
\hline
\end{tabular}

differ between the two groups, but antiemetic consumption was lower in the ketamine group [54]. Ketamine-related adverse effects, such as neuropsychiatric symptoms (confusion, hallucinations, and nightmares) and cardiovascular events, have not been reported.

In summary, there are insufficient data to support the routine use of ketamine as an adjuvant to postoperative analgesia in patients undergoing PSF for AIS. Further research is needed to determine the optimal timing, dose, and mode of the administration of ketamine when used for postoperative analgesia in these patients.

\section{Gabapentinoids}

Gabapentin and pregabalin were originally developed as anticonvulsants and have been used widely to treat chronic neuropathic pain. Recent meta-analyses show that these agents are useful as adjuvant analgesia for reducing postoperative pain, including after spine surgery [55-57]. However, only the analgesic effect of gabapentin has been studied in scoliosis correction surgery (Table 5), and the results are inconsistent. In a randomized controlled trial that included 35 patients with AIS, a single dose of oral gabapentin (600 mg, $1 \mathrm{~h}$ before surgery, $n=18$ ) did not reduce postoperative cumulative morphine consumption or pain intensity in the $72 \mathrm{~h}$ following surgery when compared with placebo $(n=17)$ [24]. In contrast, in another randomized controlled trial, multiple doses of gabapentin $(15 \mathrm{mg} / \mathrm{kg}, 30 \mathrm{~min}$ before surgery and $5 \mathrm{mg} / \mathrm{kg}$ three times daily for 5 days postoperatively, $n=29$ ) reduced the total morphine consumption in the recovery room and on postoperative days 1 and 2 by 30,16, and 23\%, respectively, in comparison with placebo $(n=30)$ [29]. Pain scores in the recovery room and on the morning after surgery were also reduced, but the differences did not reach statistical significance. In both studies, no difference in opioid-related side effects was found between the two groups. In a recent retrospective study, perioperative gabapentin $(10 \mathrm{mg} / \mathrm{kg} 1 \mathrm{~h}$ before the arrival in the operating room and $200 \mathrm{mg}$ three times a day starting on postoperative day 1 and continued until discharge from hospital) reduced the total morphine dose required by $25 \%$. However, gabapentin did not reduce the pain scores during the postoperative stay or any side effects [26].

In summary, gabapentin may have the potential to reduce pain after PSF in patients with AIS, but the optimal dosage and duration of administration are unclear. Furthermore, there is no strong evidence of the effectiveness of gabapentin as an analgesic adjuvant in this patient population, so further research is needed to confirm its efficacy.

\section{Acetaminophen/nonsteroidal anti-inflammatory drugs}

Addition of scheduled acetaminophen and/or nonsteroidal anti-inflammatory drugs (NSAIDs) to opioid-based analgesia improves analgesia and reduces opioid requirements, so preemptive use of these agents in adults is included in the recommendations of several guidelines $[33,34]$. The utility of these adjunctive analgesics in 
Table 5 Regimens for oral gabapentin reported in the literature

\begin{tabular}{|c|c|c|}
\hline $\begin{array}{l}\text { First author } \\
\text { Journal } \\
\text { Year } \\
\text { Type of study } \\
n\end{array}$ & Preoperative dose & Postoperative doses \\
\hline $\begin{array}{l}\text { Mayell [24] } \\
\text { Paediatr Anaesth } \\
2014 \\
\text { RCT } \\
35\end{array}$ & $600 \mathrm{mg} 1 \mathrm{~h}$ before surgery & None \\
\hline $\begin{array}{l}\text { Rusy [29] } \\
\text { Anaesth Analg } \\
2010 \\
\text { RCT } \\
59\end{array}$ & $\begin{array}{l}15 \mathrm{mg} / \mathrm{kg} 25-30 \mathrm{~min} \text { before being } \\
\text { taken to the OR }\end{array}$ & $\begin{array}{l}\text { At a dose of } 5 \mathrm{mg} / \mathrm{kg} \text { three times/day, } \\
\text { starting on POD } 1 \text { for } 5 \text { days }\end{array}$ \\
\hline $\begin{array}{l}\text { Choudhry [26] } \\
\text { J Pediatr Orthop } \\
2017 \\
\text { Retrospective } \\
127\end{array}$ & $\begin{array}{l}10 \mathrm{mg} / \mathrm{kg} \text { up to a maximum } \\
\text { of } 600 \mathrm{mg} 1 \mathrm{~h} \text { before going } \\
\text { to the OR }\end{array}$ & $\begin{array}{l}200 \mathrm{mg} \text { twice a day for patients }>50 \mathrm{~kg} \\
\text { body weight and } 100 \mathrm{mg} \text { three times a } \\
\text { day for patients }<50 \mathrm{~kg} \text { body weight starting } \\
\text { on POD } 1 \text { until discharge from hospital }\end{array}$ \\
\hline
\end{tabular}

$O R$ operating room, $P O D$ postoperative day, $R C T$ randomized controlled trial

children is also supported by a recent systematic review [58]. However, few studies have examined the analgesic effects of acetaminophen/NSAIDs in patients undergoing scoliosis correction surgery (Table 6). In a randomized controlled trial, acetaminophen $90 \mathrm{mg} / \mathrm{kg} /$ day IV (30 $\mathrm{mg} / \mathrm{kg}$ at the end of surgery, twice at 8 -h intervals thereafter) reduced the number of patients with a visual analog scale (VAS) pain score of $\geq 6$ within $24 \mathrm{~h}$ after surgery (7/18 patients in the acetaminophen group vs $13 / 18$ patients in the placebo group) [32]. However, there was no difference in terms of the maximum VAS score (5.5 in the acetaminophen group vs 6.5 in the placebo group) or the cumulative oxycodone dose $(1.3 \pm 0.3 \mathrm{mg} / \mathrm{kg}$ in the acetaminophen group vs 1.43 $\pm 0.4 \mathrm{mg} / \mathrm{kg}$ in the placebo group) during the first 24 postoperative hours in that study. Some studies have evaluated the analgesic efficacy of NSAIDs in scoliosis correction surgery. Munro et al. showed that ketorolac $0.5 \mathrm{mg} / \mathrm{kg}$ administered at 6 - $\mathrm{h}$ intervals postoperatively for $36 \mathrm{~h}$ reduced VAS pain scores on postoperative days 1 and 2 as well as morphine consumption in the post-anesthesia care unit and on postoperative day 2 when compared with placebo [17]. In a retrospective study that included 7349 patients undergoing PSF for AIS, the use of ketorolac was independently associated with significantly lower odds of a prolonged duration of IV opioids (odds ratio $0.84,95 \%$ confidence interval $0.73-0.98$ ) and a prolonged length of stay (odds ratio 0.75, 95\% confidence interval 0.64-0.89) [59]. Given that NSAIDs exert their analgesic effects by preventing prostaglandin synthesis via inhibition of cyclooxygenase, there has been a concern regarding the effects of NSAIDs on bone formation and healing, which are critical processes for successful spinal fusion. Animal studies have shown that NSAIDs decrease the fusion rates after spinal fusion $[60,61]$. Human studies have also shown that short-term exposure (for $<14$ days) to normal doses of NSAIDs (ketorolac, diclofenac, celecoxib, and rofecoxib) was safe after spinal fusion, whereas high-dose ketorolac ( $\geq 120 \mathrm{mg} /$ day) was associated with higher nonunion rates $[62,63]$. Another potential concern regarding the use of perioperative NSAIDs is an increased risk of postoperative bleeding. Post-marketing surveillance data and a recent meta-analysis indicate that ketorolac does not increase postoperative blood loss [64, 65].

In summary, acetaminophen and NSAIDs should be added as analgesic adjuvants unless contraindicated. High-dose ketorolac should be avoided because it may interfere with bone healing.

\section{Continuous wound infiltration}

Continuous wound infiltration (CWI), whereby local anesthetics are administered continuously by an elastomeric pump via a catheter inserted at the surgical wound site, is being used increasingly as part of multimodal analgesia. In a recent meta-analysis comparing the analgesic effect of CWI with that of epidural analgesia in patients undergoing abdominal surgery, postoperative pain scores were similar between the two groups, and the incidence of urinary retention was significantly lower in the CWI group [66]. There are several studies suggesting the usefulness of CWI in scoliosis surgery (Table 7$)$. In a retrospective study that compared patients who did $(n=129)$ and did not $(n=115)$ receive CWI, significantly fewer patients receiving CWI of bupivacaine $0.5 \%(4 \mathrm{ml} / \mathrm{h}$ for $100 \mathrm{~h}$ via a catheter placed adjacent to the spinal instrumentation, in the paraspinal muscles, in the subfascial area, or subcutaneously) required a continuous basal infusion of morphine 
Table 6 Regimens for acetaminophen/nonsteroidal anti-inflammatory drugs reported in the literature

\begin{tabular}{|c|c|c|}
\hline $\begin{array}{l}\text { First author } \\
\text { Journal } \\
\text { Year } \\
\text { Type of study } \\
\text { Total sample size }\end{array}$ & Initial dose & Subsequent doses \\
\hline $\begin{array}{l}\text { Hiller [32] } \\
\text { Spine (Phila Pa 1976) } \\
2012 \\
\text { RCT } \\
36\end{array}$ & $\begin{array}{l}\text { Acetaminophen } 30 \mathrm{mg} / \mathrm{kg} \text { IV for } 15 \mathrm{~min} \\
\text { at the time of surgical closure }\end{array}$ & $\begin{array}{l}\text { Subsequent doses of acetaminophen were given } \\
8 \text { and } 16 \mathrm{~h} \text { after the first dose }\end{array}$ \\
\hline $\begin{array}{l}\text { Munro [17] } \\
\text { Can J Anaesth } \\
2002 \\
\text { RCT } \\
35\end{array}$ & Ketorolac $0.5 \mathrm{mg} / \mathrm{kg}$ IV on completion of surgery & Repeat dosing of ketorolac every $6 \mathrm{~h}$ for a total of six doses \\
\hline $\begin{array}{l}\text { Rosenberg [59] } \\
\text { Spine (Phila Pa 1976) } \\
2016 \\
\text { Retrospective } \\
7349\end{array}$ & $\begin{array}{l}\text { No description regarding dose and timing } \\
\text { of ketorolac administration }\end{array}$ & $\begin{array}{l}\text { No description regarding dose and timing } \\
\text { of ketorolac administration }\end{array}$ \\
\hline
\end{tabular}

(32.6\% vs $85.2 \%)$, resulting in an overall reduction of opioid use on postoperative day 1 (18.9 $\mathrm{mg}$ vs $26.4 \mathrm{mg}$ ) [67]. In that study, the requirement for antiemetics was lower in patients who received CWI (91/ $129,70.5 \%)$ than in those who did not (98/115, $85.2 \%)$. The depth of catheter placement did not impact the postoperative opioid use. In another retrospective study that again compared patients who did $(n=62)$ or did not $(n=25)$ receive CWI, CWI of bupivacaine $0.25 \%$ ( $4 \mathrm{ml} / \mathrm{h}$ for $100 \mathrm{~h}$ subcutaneously) decreased the opioid consumption by $38 \%$ within $24 \mathrm{~h}$ after scoliosis correction surgery [68]. There was no difference in the incidence of adverse effects, such as PONV, pruritus, and sedation, between the two groups. However, although no catheter-related complications were reported, there is a potential risk of infection through the catheter. In a retrospective study that evaluated the effectiveness of adjunctive pain control methods, a multivariate regression analysis showed that CWI reduced normalized opioid requirements by $0.98 \mathrm{mg} / \mathrm{kg}$ and reduced VAS pain scores by 0.67 points [23].

In summary, CWI seems to be a useful analgesic adjuvant in patients undergoing PSF for AIS. The currently available data are only from retrospective trials, so further prospective studies are needed to evaluate the safety and efficacy of CWI in this patient population.

Table 7 Regimens for continuous wound infiltration of local anesthetics reported in the literature

\begin{tabular}{|c|c|c|c|}
\hline $\begin{array}{l}\text { First author } \\
\text { Journal } \\
\text { Year } \\
\text { Type of study } \\
\text { Total sample size }\end{array}$ & Position of the catheter & $\begin{array}{l}\text { Loading } \\
\text { dose }\end{array}$ & Continuous infusion \\
\hline $\begin{array}{l}\text { Ross [67] } \\
\text { Spine (Phila Pa } \\
\text { 1976) } \\
2011 \\
\text { Retrospective } \\
244\end{array}$ & $\begin{array}{l}\text { Just adjacent to the spinal instrumentation, in the paraspinal muscle, } \\
\text { in the subfascial area, or subcutaneously at the discretion of } \\
\text { the surgeon }\end{array}$ & None & Bupivacaine $0.5 \%$ at $4 \mathrm{ml} / \mathrm{h}$ for $100 \mathrm{~h}$ \\
\hline $\begin{array}{l}\text { Reynolds [68] } \\
\text { Global Spine J } \\
2013 \\
\text { Retrospective } \\
87\end{array}$ & $\begin{array}{l}\text { Two catheters inserted into the subcutaneous tissue on either } \\
\text { side of the incision site, just before wound closure }\end{array}$ & None & $\begin{array}{l}\text { Bupivacaine } 0.25 \% \text { in sterile saline at a rate } \\
\text { of } 4 \mathrm{ml} / \mathrm{h}(2 \mathrm{ml} / \mathrm{h} \text { for each catheter) for } 100 \mathrm{~h}\end{array}$ \\
\hline $\begin{array}{l}\text { Wade [23] } \\
\text { Spine Deform } \\
2015 \\
\text { Retrospective } \\
196\end{array}$ & Subcutaneously in the wound before closure & None & Bupivacaine $0.25 \%$ at $4 \mathrm{ml} / \mathrm{h}$ for $72 \mathrm{~h}$ \\
\hline
\end{tabular}




\section{Diazepam}

Diazepam is often used to prevent and treat muscle spasm after surgery for scoliosis. In general, diazepam is administered at a dose of $0.05-0.1 \mathrm{mg} / \mathrm{kg}$ every $6-12 \mathrm{~h}$ orally or IV as needed [20, 25, 28, 29, 32]. Although diazepam can suppress spasm, there is no evidence of its effect as an analgesic adjuvant [69].

\section{Other analgesics}

Apart from the analgesics mentioned above, there are some agents that may improve analgesia, but they have not been studied in patients undergoing corrective surgery for AIS.

\section{Glucocorticoids}

The efficacy of glucocorticoids for reducing pain and inflammation after surgery has been explored. A meta-analysis that included 5796 surgical patients demonstrated that a single IV dose of dexamethasone (1.25-20 mg) was associated with reductions in postoperative pain scores, opioid consumption, need for rescue analgesia, and length of stay in the post-anesthesia care unit, as well as a prolonged time to the first analgesic dose in comparison with the control group, without increasing the risks of infection or delayed wound healing [70]. Although dexamethasone has the potential to induce immunosuppression and increase the risk of infection, recent meta-analyses and a large clinical trial have shown that a single dose of dexamethasone does not increase the risk of surgical site infection in patients with or without diabetes mellitus undergoing noncardiac surgery $[71,72]$. These data suggest that a single dose of dexamethasone could be an option for adjunctive analgesia in patients undergoing correction surgery for AIS. However, further studies are needed to establish the safety and efficacy of dexamethasone in this patient population, given that spinal instrumentation can increase the risk of soft tissue infections postoperatively [73].

\section{Intravenous lidocaine}

IV lidocaine infusion has been shown to have analgesic and anti-inflammatory properties. A meta-analysis that included 2802 surgical patients showed that an IV infusion of lidocaine started at the time of surgery reduced the pain immediately after surgery (for up to $4 \mathrm{~h}$ ) and until $24 \mathrm{~h}$ in patients undergoing laparoscopic or open abdominal surgery without increasing the risk of lidocaine-associated adverse effects, including death, arrhythmias, other cardiac conduction disorders, or signs of lidocaine toxicity [74]. Moreover, several studies have demonstrated that perioperative IV lidocaine decreases the incidence of chronic postoperative pain $[75,76]$, although the dose, timing, and duration of the administration of lidocaine varied between the studies. Thus far, no studies have examined the effect of IV lidocaine infusion on acute and chronic pain in patients with AIS undergoing PSF. Further research is needed to identify the optimal use of IV lidocaine infusion in this patient population.

\section{Prophylaxis of opioid-related side effects}

As mentioned earlier, the high incidence of opioid-related adverse effects, particularly PONV and pruritus, is problematic in the management of postoperative pain in patients undergoing PSF for AIS. There are several measures that can minimize these complications. Prophylactic administration of antiemetics is the mainstay for the prevention of PONV. For patients at high risk for PONV, several antiemetics with different mechanisms of action may be needed, given that none of these agents alone has adequate prophylactic potency [77]. Dexamethasone and ondansetron are the most frequently used antiemetics in this patient population [12], although their effectiveness as antiemetics in pediatric surgery is only confirmed for minor procedures, such as tonsillectomy and strabismus surgery. There is no evidence of their antiemetic efficacy in major surgery, such as PSF for patients with AIS. Continuous administration of naloxone, an opioid antagonist, may be useful, given that this agent has been shown to reduce the incidence of pruritus and nausea without increasing the amount of analgesia needed [78, 79]. It has been reported that ondansetron may reduce opioid-induced pruritus [80]. Although there is no evidence of this as yet in pediatric cases, its use can be considered if needed.

\section{Persistent postsurgical pain in patients following scoliosis surgery}

Patients undergoing PSF often develop persistent postoperative pain (PPP) in addition to acute pain in the immediate postoperative period. A retrospective survey reported that $55(52 \%)$ of 105 patients had ongoing pain at the time of discharge from hospital [81]. In a recent prospective study of 144 adolescents who underwent scoliosis surgery, the incidence of pain was $37.8 \%$ at $2-3$ months and $41.8 \%$ at 1 year after surgery [82]. The mechanism via which PPP develops is not fully elucidated but seems to involve neuropathic and even neuroinflammatory elements [83]. Severe acute postoperative pain has been proposed as one of the risk factors that might induce PPP [84]. Therefore, preemptive or preventive strategies that block the central sensitization mechanisms might be important for the prevention of PPP. The meta-analyses suggest that several techniques, including regional anesthesia, intravenous infusion of local anesthetics, and perioperative pregabalin and ketamine, may reduce PPP [57, 85, 86], but no promising results have been obtained as yet. The development of PPP appears to be multifactorial, so a multimodal approach might afford the best chance of favorable results. 


\section{Conclusion}

In summary, a potent analgesic technique such as IV PCA or epidural anesthesia is needed for pain management after PSF for AIS. Given the complex causes of pain and the high incidence of opioid-related complications, a multimodal approach to improve analgesia and reduce opioid consumption is essential. The efficacy of intrathecal opioids and NSAIDs as components of multimodal analgesia in PSF is well established. However, there is not enough evidence for the use of other analgesics or analgesic modalities in this patient population. PPP is also problematic in this patient population. Although several preventive strategies have been proposed, no promising results have been obtained. Further studies are needed to establish the safety and efficacy of these techniques and to identify the optimal multimodal regimen.

\begin{abstract}
Abbreviations
AIS: Adolescent idiopathic scoliosis; CWI: Continuous wound infiltration; ITO: Intrathecal opioids; IV PCA: Intravenous patient-controlled analgesia; NSAIDs: Nonsteroidal anti-inflammatory drugs; PONV: Postoperative nausea and vomiting; PPP: Persistent postsurgical pain; PSF: Posterior spinal fusion; VAS: Visual analog scale
\end{abstract}

\section{Authors' contributions}

HS is the lead author responsible for the overall review and work. SI and TI were involved in the conception of the study and article review process and helped to draft the manuscript. KW, MM, and HM were involved in the conception of the study and helped to draft the manuscript. All authors read and approved the final manuscript.

\section{Ethics approval and consent to precipitate}

Not applicable.

\section{Consent for publication}

Not applicable.

\section{Competing interests}

The authors declare that they have no competing interests.

\section{Publisher's Note}

Springer Nature remains neutral with regard to jurisdictional claims in published maps and institutional affiliations.

\section{Author details}

${ }^{1}$ Department of Anesthesiology, Keio University School of Medicine, 35 Shinanomachi Shinjuku-ku, Tokyo 160-8582, Japan. ${ }^{2}$ Department of Orthopaedic Surgery, Keio University School of Medicine, 35 Shinanomachi Shinjuku-ku, Tokyo 160-8582, Japan.

Received: 4 December 2017 Accepted: 31 July 2018

Published online: 12 September 2018

\section{References}

1. Altaf F, Gibson A, Dannawi Z, Noordeen H. Adolescent idiopathic scoliosis. BMJ. 2013;346:f2508.

2. Hresko MT. Clinical practice. Idiopathic scoliosis in adolescents. N Engl J Med. 2013;368:834-41.

3. Bajwa SJ, Haldar R. Pain management following spinal surgeries: an appraisal of the available options. J Craniovertebr Junction Spine. 2015;6: 105-10.

4. Gerbershagen HJ, Pogatzki-Zahn E, Aduckathil S, Peelen LM, Kappen TH, van Wijck AJ, et al. Procedure-specific risk factor analysis for the development of severe postoperative pain. Anesthesiology. 2014;120:1237-45.
5. Gagliese L, Gauthier LR, Macpherson AK, Jovellanos M, Chan WW. Correlates of postoperative pain and intravenous patient-controlled analgesia use in younger and older surgical patients. Pain Med. 2008;9:299-314.

6. Fletcher D, Stamer UM, Pogatzki-Zahn E, Zaslansky R, Tanase NV, Perruchoud C, et al. Chronic postsurgical pain in Europe: an observational study. Eur J Anaesthesiol. 2015;32:725-34.

7. Rullander AC, Jonsson $H$, Lundstrom $M$, Lindh V. Young people's experiences with scoliosis surgery: a survey of pain, nausea, and global satisfaction. Orthop Nurs. 2013;32:327-33. quiz 34-5

8. Kehlet H, Dahl JB. The value of "multimodal" or "balanced analgesia" in postoperative pain treatment. Anesth Analg. 1993;77:1048-56.

9. Andersen LO, Gaarn-Larsen L, Kristensen BB, Husted H, Otte KS, Kehlet H. Subacute pain and function after fast-track hip and knee arthroplasty. Anaesthesia. 2009;64:508-13.

10. Moher D, Liberati A, Tetzlaff J, Altman DG, Group P. Preferred reporting items for systematic reviews and meta-analyses: the PRISMA statement. BMJ. 2009;339:b2535.

11. Berde CB, Sethna NF. Analgesics for the treatment of pain in children. $N$ Engl J Med. 2002;347:1094-103.

12. Palmer GM, Pirakalathanan P, Skinner AV. A multi-centre multi-national survey of anaesthetists regarding the range of anaesthetic and surgical practices for paediatric scoliosis surgery. Anaesth Intensive Care. 2010;38:1077-84.

13. Bird S, McGill N. Blood conservation and pain control in scoliosis corrective surgery: an online survey of UK practice. Paediatr Anaesth. 2011;21:50-3.

14. Weldon BC, Connor M, White PF. Pediatric PCA: the role of concurrent opioid infusions and nurse-controlled analgesia. Clin J Pain. 1993;9:26-33.

15. Beaulieu P, Cyrenne L, Mathews S, Villeneuve E, Vischoff D. Patientcontrolled analgesia after spinal fusion for idiopathic scoliosis. Int Orthop. 1996:20:295-9.

16. Cassady JF Jr, Lederhaas G, Cancel DD, Cummings RJ, Loveless EA. A randomized comparison of the effects of continuous thoracic epidural analgesia and intravenous patient-controlled analgesia after posterior spinal fusion in adolescents. Reg Anesth Pain Med. 2000;25:246-53.

17. Munro HM, Walton SR, Malviya S, Merkel S, Voepel-Lewis T, Loder RT, et al. Low-dose ketorolac improves analgesia and reduces morphine requirements following posterior spinal fusion in adolescents. Can J Anaesth. 2002;49:461-6.

18. Sucato DJ, Duey-Holtz A, Elerson E, Safavi F. Postoperative analgesia following surgical correction for adolescent idiopathic scoliosis: a comparison of continuous epidural analgesia and patient-controlled analgesia. Spine (Phila Pa 1976). 2005;30:211-7.

19. Crawford MW, Hickey C, Zaarour C, Howard A, Naser B. Development of acute opioid tolerance during infusion of remifentanil for pediatric scoliosis surgery. Anesth Analg. 2006;102:1662-7.

20. Gauger VT, Voepel-Lewis TD, Burke CN, Kostrzewa AJ, Caird MS, Wagner DS, et al. Epidural analgesia compared with intravenous analgesia after pediatric posterior spinal fusion. J Pediatr Orthop. 2009;29:588-93.

21. Milbrandt TA, Singhal M, Minter C, McClung A, Talwalkar VR, Iwinski HJ, et al. A comparison of three methods of pain control for posterior spinal fusions in adolescent idiopathic scoliosis. Spine (Phila Pa 1976). 2009;34:1499-503.

22. Sadhasivam S, Boat A, Mahmoud M. Comparison of patient-controlled analgesia with and without dexmedetomidine following spine surgery in children. J Clin Anesth. 2009;21:493-501.

23. Wade Shrader M, Nabar SJ, Jones JS, Falk M, Cotugno R, White GR, et al. Adjunctive pain control methods lower narcotic use and pain scores for patients with adolescent idiopathic scoliosis undergoing posterior spinal fusion. Spine Deform. 2015:3:82-7.

24. Mayell A, Srinivasan I, Campbell F, Peliowski A. Analgesic effects of gabapentin after scoliosis surgery in children: a randomized controlled trial. Paediatr Anaesth. 2014;24:1239-44.

25. Klatt JW, Mickelson J, Hung M, Durcan S, Miller C, Smith JT. A randomized prospective evaluation of 3 techniques of postoperative pain management after posterior spinal instrumentation and fusion. Spine (Phila Pa 1976). 2013;38:1626-31.

26. Choudhry DK, Brenn BR, Sacks K, Shah S. Evaluation of Gabapentin and Clonidine Use in Children Following Spinal Fusion Surgery for Idiopathic Scoliosis: A Retrospective Review. J Pediatr Orthop; 2017. [Epub ahead of print]

27. Perello M, Artes D, Pascuets C, Esteban E, Ey Batlle AM. Prolonged perioperative low-dose ketamine does not improve short and long-term outcomes after pediatric idiopathic scoliosis surgery. Spine (Phila Pa 1976). 2017;42:E304-E12 
28. Pestieau SR, Finkel JC, Junqueira MM, Cheng Y, Lovejoy JF, Wang J, et al. Prolonged perioperative infusion of low-dose ketamine does not alter opioid use after pediatric scoliosis surgery. Paediatr Anaesth. 2014;24:582-90.

29. Rusy LM, Hainsworth KR, Nelson TJ, Czarnecki ML, Tassone JC, Thometz JG, et al. Gabapentin use in pediatric spinal fusion patients: a randomized, double-blind, controlled trial. Anesth Analg. 2010;110:1393-8.

30. Engelhardt T, Zaarour C, Naser B, Pehora C, de Ruiter J, Howard A, et al. Intraoperative low-dose ketamine does not prevent a remifentanil-induced increase in morphine requirement after pediatric scoliosis surgery. Anesth Analg. 2008;107:1170-5.

31. O'Hara JF Jr, Cywinski JB, Tetzlaff JE, Xu M, Gurd AR, Andrish JT. The effect of epidural vs intravenous analgesia for posterior spinal fusion surgery. Paediatr Anaesth. 2004;14:1009-15.

32. Hiller A, Helenius I, Nurmi E, Neuvonen PJ, Kaukonen M, Hartikainen T, et al. Acetaminophen improves analgesia but does not reduce opioid requirement after major spine surgery in children and adolescents. Spine (Phila Pa 1976). 2012;37:E1225-31.

33. Apfelbaum JL, Ashburn MA, Connis RT, Gan TJ, Nickinovich DG, Caplan RA, et al. Practice guidelines for acute pain management in the perioperative setting: an updated report by the American Society of Anesthesiologists Task Force on Acute Pain Management. Anesthesiology. 2012;116:248-73.

34. Chou R, Gordon DB, de Leon-Casasola OA, Rosenberg JM, Bickler S, Brennan $T$, et al. Management of postoperative pain: a clinical practice guideline from the American Pain Society, the American Society of Regional Anesthesia and Pain Medicine, and the American Society of Anesthesiologists' Committee on Regional Anesthesia, Executive Committee, and Administrative Council. J Pain. 2016;17:131-57.

35. Misiolek H, Cettler M, Woron J, Wordliczek J, Dobrogowski J, MayznerZawadzka E. The 2014 guidelines for post-operative pain management. Anaesthesiol Intensive Ther. 2014;46:221-44.

36. Nelson KL, Yaster M, Kost-Byerly S, Monitto CL. A national survey of American pediatric anesthesiologists: patient-controlled analgesia and other intravenous opioid therapies in pediatric acute pain management. Anesth Analg. 2010;1 10:754-60.

37. George JA, Lin EE, Hanna MN, Murphy JD, Kumar K, Ko PS, et al. The effect of intravenous opioid patient-controlled analgesia with and without background infusion on respiratory depression: a meta-analysis. J Opioid Manag. 2010;6:47-54.

38. Hayes J, Dowling JJ, Peliowski A, Crawford MW, Johnston B. Patientcontrolled analgesia plus background opioid infusion for postoperative pain in children: a systematic review and meta-analysis of randomized trials. Anesth Analg. 2016;123:991-1003.

39. Poe-Kochert C, Tripi PA, Potzman J, Son-Hing JP, Thompson GH. Continuous intravenous morphine infusion for postoperative analgesia following posterior spinal fusion for idiopathic scoliosis. Spine (Phila Pa 1976). 2010;35:754-7.

40. Blumenthal S, Min K, Nadig M, Borgeat A. Double epidural catheter with ropivacaine versus intravenous morphine: a comparison for postoperative analgesia after scoliosis correction surgery. Anesthesiology. 2005;102:175-80.

41. Saudan S, Habre W, Ceroni D, Meyer PA, Greenberg RS, Kaelin A, et al. Safety and efficacy of patient controlled epidural analgesia following pediatric spinal surgery. Paediatr Anaesth. 2008;18:132-9.

42. Tobias JD, Gaines RW, Lowry K, Kittle D, Bildner C. A dual epidural catheter technique to provide analgesia following posterior spinal fusion for scoliosis in children and adolescents. Paediatr Anaesth. 2001;11:199-203.

43. Erdogan MA, Ozgul U, Ucar M, Korkmaz MF, Aydogan MS, Ozkan AS, et al. Patient-controlled intermittent epidural bolus versus epidural infusion for posterior spinal fusion after adolescent idiopathic scoliosis: prospective, randomized, double-blinded study. Spine (Phila Pa 1976). 2017;42:882-6.

44. Dolin SJ, Cashman JN. Tolerability of acute postoperative pain management: nausea, vomiting, sedation, pruritus, and urinary retention. Evidence from published data. Br J Anaesth. 2005;95:584-91.

45. Goodarzi M. The advantages of intrathecal opioids for spinal fusion in children. Paediatr Anaesth. 1998:8:131-4.

46. Gall O, Aubineau JV, Berniere J, Desjeux L, Murat I. Analgesic effect of lowdose intrathecal morphine after spinal fusion in children. Anesthesiology. 2001;94:447-52.

47. Eschertzhuber S, Hohlrieder M, Keller C, Oswald E, Kuehbacher G, Innerhofer P. Comparison of high- and low-dose intrathecal morphine for spinal fusion in children. Br J Anaesth. 2008;100:538-43.

48. Tripi PA, Poe-Kochert C, Potzman J, Son-Hing JP, Thompson GH. Intrathecal morphine for postoperative analgesia in patients with idiopathic scoliosis undergoing posterior spinal fusion. Spine (Phila Pa 1976). 2008;33:2248-51.
49. Son-Hing JP, Poe-Kochert C, Thompson GH, Potzman J, Tripi PA. Intrathecal morphine analgesia in idiopathic scoliosis surgery: does sex or racial group affect optimal dosing? J Pediatr Orthop. 2011;31:489-95.

50. Hong RA, Gibbons KM, Li GY, Holman A, Voepel-Lewis T. A retrospective comparison of intrathecal morphine and epidural hydromorphone for analgesia following posterior spinal fusion in adolescents with idiopathic scoliosis. Paediatr Anaesth. 2017;27:91-7.

51. Cohen M, Zuk J, McKay N, Erickson M, Pan Z, Galinkin J. Intrathecal Morphine Versus Extended-Release Epidural Morphine for Postoperative Pain Control in Pediatric Patients Undergoing Posterior Spinal Fusion. Anesth Analg. 2017;124:2030-7.

52. Wang L, Johnston B, Kaushal A, Cheng D, Zhu F, Martin J. Ketamine added to morphine or hydromorphone patient-controlled analgesia for acute postoperative pain in adults: a systematic review and meta-analysis of randomized trials. Can J Anaesth. 2016;63:311-25.

53. Pendi A, Field R, Farhan SD, Eichler M, Bederman SS. Perioperative Ketamine for Analgesia in Spine Surgery: A Meta-analysis of Randomized Controlled Trials. Spine (Phila Pa 1976). 2017;43:E299-E307.

54. Minoshima R, Kosugi S, Nishimura D, Ihara N, Seki H, Yamada T, et al. Intraand postoperative low-dose ketamine for adolescent idiopathic scoliosis surgery: a randomized controlled trial. Acta Anaesthesiol Scand. 2015;59: 1260-8.

55. Doleman B, Heinink TP, Read DJ, Faleiro RJ, Lund JN, Williams JP. A systematic review and meta-regression analysis of prophylactic gabapentin for postoperative pain. Anaesthesia. 2015;70:1186-204.

56. Peng C, Li C, Qu J, Wu D. Gabapentin can decrease acute pain and morphine consumption in spinal surgery patients: a meta-analysis of randomized controlled trials. Medicine (Baltimore). 2017;96:e6463.

57. Mishriky BM, Waldron NH, Habib AS. Impact of pregabalin on acute and persistent postoperative pain: a systematic review and meta-analysis. Br J Anaesth. 2015;114:10-31.

58. Wong I, St John-Green C, Walker SM. Opioid-sparing effects of perioperative paracetamol and nonsteroidal anti-inflammatory drugs (NSAIDs) in children. Paediatr Anaesth. 2013;23:475-95.

59. Rosenberg RE, Trzcinski S, Cohen M, Erickson M, Errico T, McLeod L. The Association between Adjuvant Pain Medication Use and Outcomes Following Pediatric Spinal Fusion. Spine (Phila Pa 1976). 2017;42:E602-8.

60. Riew K, Long J, Rhee J, Lewis S, Kuklo T, Kim Y, et al. Time-dependent inhibitory effects of indomethacin on spinal fusion. J Bone Joint Surg Am. 2003:85:632-4.

61. Martin GJ, Boden S, Titus L. Recombinant human bone morphogenetic protein-2 overcomes the inhibitory effect of ketorolac, a nonsteroidal antiinflammatory drug (NSAID), on posterolateral lumbar intertransverse process spine fusion. Spine. 1999;1 (24):2188-93.

62. Li Q, Zhang Z, Cai Z. High-dose ketorolac affects adult spinal fusion: a metaanalysis of the effect of perioperative nonsteroidal anti-inflammatory drugs on spinal fusion. Spine (Phila Pa 1976). 2011;36:E461-8.

63. Reuben SS, Ablett D, Kaye R. High dose nonsteroidal anti-inflammatory drugs compromise spinal fusion. Can J Anaesth. 2005;52:506-12.

64. Strom BL, Berlin JA, Kinman JL, Spitz PW, Hennessy S, Feldman H, et al. Parenteral ketorolac and risk of gastrointestinal and operative site bleeding. A postmarketing surveillance study. JAMA. 1996;275:376-82.

65. Gobble RM, Hoang HL, Kachniarz B, Orgill DP. Ketorolac does not increase perioperative bleeding: a meta-analysis of randomized controlled trials. Plast Reconstr Surg. 2014;133:741-55.

66. Ventham NT, Hughes M, O'Neill S, Johns N, Brady RR, Wigmore SJ. Systematic review and meta-analysis of continuous local anaesthetic wound infiltration versus epidural analgesia for postoperative pain following abdominal surgery. Br J Surg. 2013;100:1280-9.

67. Ross PA, Smith BM, Tolo VT, Khemani RG. Continuous infusion of bupivacaine reduces postoperative morphine use in adolescent idiopathic scoliosis after posterior spine fusion. Spine (Phila Pa 1976). 2011;36:1478-83.

68. Reynolds RA, Legakis JE, Tweedie J, Chung Y, Ren EJ, Bevier PA, et al. Postoperative pain management after spinal fusion surgery: an analysis of the efficacy of continuous infusion of local anesthetics. Global Spine J. 2013; $3: 7-14$.

69. Blumenkopf B. Combination analgesic-antispasmodic therapy in postoperative pain. Spine (Phila Pa 1976). 1987;12:384-7.

70. Waldron NH, Jones CA, Gan TJ, Allen TK, Habib AS. Impact of perioperative dexamethasone on postoperative analgesia and side-effects: systematic review and meta-analysis. Br J Anaesth. 2013;110:191-200. 
71. Toner AJ, Ganeshanathan V, Chan MT, Ho KM, Corcoran TB. Safety of perioperative glucocorticoids in elective noncardiac surgery: a systematic review and meta-analysis. Anesthesiology. 2017;126:234-48.

72. Corcoran T, Kasza J, Short TG, O'Loughlin E, Chan MT, Leslie K, et al. Intraoperative dexamethasone does not increase the risk of postoperative wound infection: a propensity score-matched post hoc analysis of the ENIGMA-II trial (EnDEX). Br J Anaesth. 2017;118:190-9.

73. Gerometta A, Rodriguez Olaverri JC, Bitan F. Infections in spinal instrumentation. Int Orthop. 2012;36:457-64.

74. Kranke P, Jokinen J, Pace NL, Schnabel A, Hollmann MW, Hahnenkamp K, et al. Continuous intravenous perioperative lidocaine infusion for postoperative pain and recovery. Cochrane Database Syst Rev. 2015: CD009642.

75. Grigoras A, Lee P, Sattar F, Shorten G. Perioperative intravenous lidocaine decreases the incidence of persistent pain after breast surgery. Clin J Pain. 2012;28:567-72.

76. Terkawi AS, Sharma S, Durieux ME, Thammishetti S, Brenin D, Tiouririne M. Perioperative lidocaine infusion reduces the incidence of post-mastectomy chronic pain: a double-blind, placebo-controlled randomized trial. Pain Physician. 2015;18:E139-46.

77. Gan TJ, Diemunsch P, Habib AS, Kovac A, Kranke P, Meyer TA, et al. Consensus guidelines for the management of postoperative nausea and vomiting. Anesth Analg. 2014;118:85-113.

78. Murphy JD, Gelfand HJ, Bicket MC, Ouanes JP, Kumar KK, Isaac GR, et al. Analgesic efficacy of intravenous naloxone for the treatment of postoperative pruritus: a meta-analysis. J Opioid Manag. 2011;7:321-7.

79. Miller JL, Hagemann TM. Use of pure opioid antagonists for management of opioid-induced pruritus. Am J Health Syst Pharm. 2011;68:1419-25.

80. Bonnet MP, Marret E, Josserand J, Mercier FJ. Effect of prophylactic 5-HT3 receptor antagonists on pruritus induced by neuraxial opioids: a quantitative systematic review. Br J Anaesth. 2008;101:311-9.

81. Wong GT, Yuen VM, Chow BF, Irwin MG. Persistent pain in patients following scoliosis surgery. Eur Spine J. 2007;16:1551-6.

82. Chidambaran V, Ding L, Moore DL, Spruance K, Cudilo EM, Pilipenko V, et al. Predicting the pain continuum after adolescent idiopathic scoliosis surgery: a prospective cohort study. Eur J Pain. 2017;21:1252-65.

83. Kehlet $\mathrm{H}$, Jensen $\mathrm{TS}$, Woolf $\mathrm{CJ}$. Persistent postsurgical pain: risk factors and prevention. Lancet. 2006;367:1618-25.

84. Gan TJ. Poorly controlled postoperative pain: prevalence, consequences, and prevention. J Pain Res. 2017;10:2287-98.

85. Weinstein EJ, Levene JL, Cohen MS, Andreae DA, Chao JY, Johnson M, et al. Local anaesthetics and regional anaesthesia versus conventional analgesia for preventing persistent postoperative pain in adults and children. Cochrane Database Syst Rev. 2018:6:CD007105.

86. Klatt E, Zumbrunn T, Bandschapp O, Girard T, Ruppen W. Intra- and postoperative intravenous ketamine does not prevent chronic pain: a systematic review and meta-analysis. Scand J Pain. 2017;7:42-54.

Ready to submit your research? Choose BMC and benefit from:

- fast, convenient online submission

- thorough peer review by experienced researchers in your field

- rapid publication on acceptance

- support for research data, including large and complex data types

- gold Open Access which fosters wider collaboration and increased citations

- maximum visibility for your research: over $100 \mathrm{M}$ website views per year

At $\mathrm{BMC}$, research is always in progress.

Learn more biomedcentral.com/submissions 